\title{
"Using the Language of Christian Love and Charity": What Liberal Religion Offers Higher Education in Prison
}

\author{
Charles Atkins ${ }^{1}$, Joshua Dubler ${ }^{2}$, Vincent Lloyd ${ }^{3, *}$ and Mel Webb ${ }^{4, *}$ \\ 1 Institut d'études religieuses, Université de Montréal, Montréal, QC H3T 1N8, Canada; \\ atkinsquest@gmail.com \\ 2 Religion and Classics, University of Rochester, Rochester, NY 14627, USA; joshua.dubler@rochester.edu \\ 3 Theology and Religious Studies, Villanova University, Villanova, PA 19085, USA \\ 4 Center for Civic Engagement, University of Texas San Antonio, San Antonio, TX 78249, USA \\ * Correspondance: vincent.lloyd@villanova.edu (V.L.); mgmwebb@gmail.com (M.W.)
}

Received: 7 February 2019; Accepted: 26 February 2019; Published: 7 March 2019

check for updates

\begin{abstract}
This article explores what religious frameworks and institutions have to contribute to college-in-prison. We first provide an historical overview of higher education programs in American prisons. Then, we limn the role religion can play in motivating people to commit themselves to educating incarcerated people. Because this work is so thorny, we document some of the generic challenges programs must face and show how religious languages can be an asset in navigating these challenges. Next, we present the pedagogical practices and educational philosophies expressed among the programs in our study. We conclude with some broader reflections about teaching incarcerated people, and, after wrestling with objections, we encourage our colleagues in religious studies-those with faith commitments as well as those without them-to get involved.
\end{abstract}

Keywords: prison education; Protestantism; pedagogy; mass incarceration; justice; transformation

\section{Introduction}

The exponential growth of the U.S. prison population over the past half-century is now widely recognized as a moral crisis. The United States has $4.4 \%$ of the world's population but incarcerates over a fifth of the world's prisoners. Mass incarceration and mass criminalization overwhelmingly target poor people and people of color. In part due to The New Jim Crow phenomenon, for many Americans it is now a matter of common sense that to be a prisoner in America is more a measure of demographic destiny than of moral viciousness (Alexander 2012). ${ }^{1}$ Though we hide them away, the 2.3 million men and women locked up in our prisons, jails, and immigrant detention centers represent, in a sense, only the most visible segment of the targeted population (Wacquant 2010, p. 80). ${ }^{2}$ For millions more on parole, probation, or facing outstanding charges, snowballing procedures of administrative surveillance and financial penalty often result in permanent social precarity. For others, the rhythms of life are shaped by the limited, costly opportunities to visit incarcerated loved ones.

As chaplains and as religious volunteers, free people with faith commitments have been actively engaged with incarcerated people for as long as there have been prisons. Of late, as the issue has newly kindled the fires of righteous disgust, religious and secular communities are engineering new responses and resuscitating older ones. Among academics, an increasingly prominent response has

\footnotetext{
1 For a critique see (Forman 2012).

2 For a breakdown of the 2.3 million people presently incarcerated see https://www.prisonpolicy.org/reports/pie2017.html.
} 
been to get involved with prison teaching. Yet recent books on prison education, such as College in Prison: Reading in the Age of Mass Incarceration by Daniel Karpowitz and Liberating Minds: The Case for College in Prison by Ellen Condliffe Lagemann, have not shown much of an interest in religion. ${ }^{3}$ On the one hand, this omission reveals a secularist bias common to many prison educators. When religious education makes an appearance in this discourse, the religious education in question is Christian evangelical; religious liberals, who have long been champions of prison education are largely written out of the story. We write this essay as a group of critically committed prison educators with two goals in mind: to restore the missing religion into the prison education narrative and to encourage our colleagues - especially those who work at institutions with religious affiliations- to enlist their schools to get involved in this delicate but vital work.

\section{A Calling: Starting a Program at Saint Louis University}

In April 2007 Kenneth Parker, then a faculty member in the Theology Department at Saint Louis University (SLU), happened to watch an episode of 60 Minutes that featured the Bard Prison Initiative. ${ }^{4}$ Parker immediately recognized the consonance with his institution's Jesuit mission, which proclaims a dedication "to leadership in the continuing quest for understanding of God's creation and for the discovery, dissemination, and integration of the values, knowledge, and skills required to transform society in the spirit of the Gospels" (Parker 2014, p. 380n24). In watching the 60 Minutes segment, Parker could not help but think of The Spiritual Exercises and Ignatius of Loyola's invitation to members of the Society of Jesus to internalize "the experience of 'the prisoner' and [identify] with those incarcerated and destined for execution" (Parker 2014, p. 378).

Even so, Parker felt he could not possibly start a prison program, given his already substantial set of professional responsibilities. The next day, however, he crossed paths with one of his long-term tenants who had seen the same program. Her off-handed remark challenged him to trust his enthusiasm: "You know, you're never too busy to do the right thing, once you see that it needs to be done." Spurred by this chance encounter, Parker reached out to a religious sister who facilitated programs in Missouri's prisons, and she connected him with administrators at two nearby prisons, each of whom proved open to running a pilot program. When Parker took the sister up on her offer to visit one of her sessions, he discovered that the incarcerated men were also bullish about the possibility of pursuing a college education.

Parker took the idea to his department, and his concrete proposal for a five-course Pilot Certificate in Theological Studies received unanimous endorsement. He sought funding from a local organization focused on addressing the impact of incarceration in St. Louis, and though the group was not in the habit of partnering with universities, they pledged their support. With his department chair, Parker took the idea to the Dean of Arts and Sciences who met their proposal with enthusiasm. Prison teaching resonated with the Dean's sense of what SLU was about, and henceforth "at each step of the way the mission-driven character of the initiative proved the winning argument for its approval" (Parker 2014, pp. 387-88).

Administratively speaking, getting SLU on board was, of course, only half the challenge. Parker met with the deputy warden at the Department of Corrections' Eastern Reception, Diagnosis and Correctional Center (ERDCC), the 2500-bed facility about an hour south of St. Louis which serves as the entry point for men convicted in Missouri's eastern counties. In what would become a familiar objection, the deputy warden asked Parker why he should enable free higher education for people who have committed crimes when the deputy warden, himself, was still paying off the loans from his own education? The answer, the two men agreed, was that such opportunities have been shown to reduce recidivism. The proposal was circulated to others at ERDCC and to the central offices of the Missouri Department of Corrections. The Friday before Christmas, approval came down for a program to launch the following month, which it did.

3 Lagemann offers a cursory survey of a handful of programs administered by religious institutions (Lagemann 2016, pp. 162-64). Karpowitz describes his students' theologically inflected responses to Dostoevsky (Karpowitz 2017, pp. 86-87, 89-90). See also (Castro et al. 2015).

4 The account in this section draws on (Parker 2014). 
Parker was overwhelmed by the seriousness that his incarcerated students brought to the classroom, just as he was at times overwhelmed by the window afforded by the classroom encounter into the "tragedy and brokenness" of his students' lives. In tandem, these two reactions affirmed Parker's faith in the enterprise. As he would later reflect, "Our studies together laid the groundwork for hope and the opening of possibilities that could not have been imagined before SLU became involved in their lives." The opening of possibility Parker observed was not limited to the program's incarcerated participants. The pedagogical encounter left its marks on faculty as well. "My colleagues came back changed people, more deeply committed to teaching on the main campus, and profoundly troubled by the alternative world that existed inside prison fences" (Parker 2014, p.391).

One year later, at the program's first certificate ceremony, graduate Raymond Scott made reference to Matthew 25:35 to make sense of his experience. Prior to the program, "I was a stranger to myself, to my spiritual self-but not anymore. The professors helped me find my dignity again. I am no longer naked. Indeed they helped clothe me-not only with dignity, but with the sense of self-worth that we all hunger and thirst for" (Parker 2014, p. 392). Armed with this powerful testimony, Parker pressed on and forged new partnerships across the university. Now a decade in, SLU's program at ERDCC offers an Associate of Arts degree that is open not only to the incarcerated men, but to prison staff as well.

\section{Driving Questions: Transformation and Prison Education}

Kenneth Parker's account joins ancient and medieval Christian ethics with secular spirituality, it showcases the intersection of personal commitments with institutional religion, and it demonstrates the selective salience of religious arguments to move institutional gatekeepers. The story demonstrates an institutionally situated religious response to American mass incarceration. For Parker, and for administrators at Saint Louis University, incarceration-and the condition of incarcerated people-represents a privileged site for thinking about moral obligation, personal redemption, and social transformation. For these reasons, teaching the humanities in prisons presented itself as an obvious and compelling mode of direct engagement.

This is nothing new. For as long as the United States has kept people in cages, clergy and laity have strained to directly engage with this needy population. Prison ministry offers one route, and prison education offers another. Not always does a bright line separate these two activities, and what little attention religious higher-education in prison receives generally goes to the sort of programs that willfully blur these lines. In God in Captivity: The Rise of Faith-Based Prison Ministries in the Age of Mass Incarceration, Tanya Erzen writes about New Orleans Baptist Theological Seminary, which now runs five programs in four southern states. A theologically conservative program, NOBTS's primary goal is to save souls, but its secondary goal (which also furthers the first) is to transform the prison system. Selecting exclusively for students with decades left on their sentences, NOBTS seeks to "transform" its graduates. These "transformed" people are then disseminated throughout the state's system, where, via ministry and behavioral modeling, they become a force for personal salvation and institutional order. $^{5}$ Theological imperatives dovetail nicely with custodial imperatives; and, with seminary staff doing the teaching and incarcerated volunteers tasked with the heaviest lifting, NOBTS's design fits hand-in-glove with neoliberal imperatives as well.

Erzen is broadly critical of the religious ideology of "personal transformation", which, she fears, makes those with the least power most responsible for social change while simultaneously absolving the precipitating social structures that engender poverty, crime, and social neglect. As she writes, "The faith-based ministries flock to prisons to convert, pray, teach, and proselytize, but they tend to neglect why people end up there in the first place" (Erzen 2017, p. 8). Moreover, making indigent incarcerated people overwhelmingly responsible for their own educations is, from an administrative standpoint, exceedingly cost effective. While her critique may well be valid for the southern, evangelical-friendly

5 See (Erzen 2017). Other southern seminaries and prison systems have adopted NOBTS's model: Southwestern Baptist Theological Seminary is in Barrington Prison in Houston, TX, and Southeastern is beginning a program in North Carolina. 
correctional facilities that she studied, our study takes into account programs that were not covered in Erzen's work. Our research also highlights the perspectives of organizations for which prison programs are only one facet of their multilevel work toward changing the prison system. For many of the programs we have surveyed, "personal transformation" is a priority that must accompany the work of changing the social structures and policies that have created the American incarceration systems.

"Religious interventions in prison," Karpowitz worries, "may be increasingly embraced by the political establishment that oversees state prison systems, by officials who see them as the most appropriate form of public-private partnership" (Karpowitz 2017, p. 95). This secular suspicion may also be found on the ground. Those who teach in secular prison programs often contrast their efforts of inculcating critical thinking skills with the chaplains' presumed propensity for disciplining docility. Religious discourses are generally configured much more as a problem than as a resource. ${ }^{6}$

We write not to promote religion, but rather to add depth and complexity to the story being told. Among our four authors are people involved in prison teaching and program administration, in academia, and in prison chaplaincy. Among us are people of faith and secular people, those committed to prison reform and those committed to prison abolition. In May 2015 we convened a group of fifteen scholars who work at the intersection of the study of religion and higher education in prison for a one-day symposium. Among the concerns that emerged was a cluster of questions pertaining to what we loosely dubbed "religious higher education in prison". ${ }^{7}$ Among our questions: How, if at all, are religiously-affiliated prison educators distinctive in terms of their pedagogies, their motivations, and their responsiveness to the challenges of teaching in a prison environment? What insights, if any, might religious scholars and scholars of religion have to share with secular prison educators, on the one hand, or with their own colleagues, on the other?

To pursue these questions, we conducted a detailed, written survey of college-in-prison programs at religiously-affiliated (or in a few cases formerly religiously-affiliated) colleges and universities. Survey questions ranged from historical to practical to pedagogical; we also included questions about mission and vision. Drawing on earlier research, advice from knowledgeable colleagues, and referrals from programs we contacted, we identified fifteen relevant programs to survey. We received nine completed surveys from program administrators. ${ }^{8}$ We reached out to additional program administrators through

6 For instance, Kenneth Parker's account appeared in a special issue of Saint Louis University's Public Law Review featuring papers presented at the 2013 National Conference on Prison Higher Education. Of the fifteen texts included in that special issue, only those by SLU faculty stress religion as a positive force. See also (Earhart 2014). Surely more indicative of community attitudes is (Stern 2014, p. 458), which couples Christian theology to American attitudes about punishment and which holds "religious ideology responsible, in large part, for our punishment crisis."

7 While many volunteer-run education programs in prisons are staffed by religious volunteers from churches, ministries, and other non-profits, our study focuses on education programs offered by either formerly or currently religiously-affiliated institutions of higher education.

8 Throughout this article, we quote from survey responses and interview notes that are on file with the authors. We received survey responses from program leaders of the following programs: (1) Certificate in Theological Studies at Arrendale State Prison for Women (Candler School of Theology)_Atlanta, GA; (2) Certification in Theology and Ministry-Inside (Princeton Theological Seminary)—Garden State Youth Correctional Facility (Bordentown, NJ); (3) Engaging, Educating, Empowering Means Change (E3MC) (Manhattan College)—Rikers Island; (4) Greenville College Prison Program-Greenville Federal Correctional Institute; (5) Higher Education Program with DePauw University, Butler, Indiana University-Indiana Women's Prison; (6) Lansing Prison Program with Donnelly Community College-Lansing Correctional Facility (Lansing, KS); (7) Liberal Arts in Prison Program at Grinnell College-Newton Correctional Facility, State Training School for Boys; (8) Project TURN (Transform, Unlock, ReNew) (Duke Divinity School)-The Raleigh Unit of North Carolina Correctional Center for Women in Raleigh, NC; Central Prison in Raleigh, NC; Federal Correctional Complex in Butner, NC; (9) Saint Louis University Prison Program-Eastern Reception, Diagnostic and Correctional Center (Bonne Terre, MO, USA) and Federal Correctional Institution-Greenville (Greenville, IL, USA). 
in-person meetings or phone conversations. ${ }^{9}$ In total, in one form or another, we substantively engaged representatives from eighteen different programs.

In a country where the bounds between the religious and the secular are not so easily delineated, it is not always obvious where secular prison education ends and religious prison education begins. In conducting our research, we decided to cast a relatively wide net. We targeted exclusively programs doing higher education, on site, and we included both degree-granting programs and non-degree-granting programs. ${ }^{10}$ For our sample, we included schools with explicit denominational ties and schools for which religion is a legible component of their institutional identity, whether it be part of a university's stated mission or in a school's institutional roots. ${ }^{11}$

The results were predictably varied, but several common nodes and themes emerged. "Religion" proved to be a slippery entity. In some cases, explicitly religious languages inform program missions and are prominent in the classroom. In others, theological ideals and religious values are absent, or even disavowed. In only a few of our survey responses are prayer and other religious rituals featured in the classroom experience. Whether or not as articulated in religious terms, all respondents and interlocutors teaching college in prison described themselves as having a calling or vocation. Whether in religious or secular idioms, administrators and teachers sought to locate their efforts as part of broader effort toward social transformation. In sum, we realized in examining our data that we had identified a robust landscape of religious liberalism —of prison educators at mainline Protestant and Catholic institutions who were being left out of the "religious" college-in-prison story.

Each of the sections that follow picks up on themes introduced in Kenneth Parker's story and showcases some of what religious frameworks and institutions have to contribute to college-in-prison. We first provide an historical overview of higher education programs in American prisons. Second, we explore the role religion can play in motivating people to commit themselves to educating those incarcerated. Third, because this work is so thorny, we document some of the generic challenges programs must face and show how religious languages can be an asset in navigating these challenges. Fourth, we present the pedagogical practices and educational philosophies expressed among the programs in our study. We conclude with some broader reflections about teaching incarcerated people, and, after wrestling with objections, we encourage our colleagues in religious studies-those with faith commitments as well as those without them-to get involved.

\section{History: Prison Education and Religious Education}

For the first hundred years of our nation's history, prison education was religious education. ${ }^{12}$ Where educating the incarcerated was a priority (and mostly it was not), chaplains were the teachers and the Bible was the curriculum. The Second Great Awakening's enthusiasm for educating the

9 We have talked with current or former program leaders of the following programs: (1) Drew University's Partnership for Religion and Prison (PREP) Program-Edna Mahan Correctional Facility for Women and Northern State Prison; (2) Mercy College Program with Marymount Manhattan (ended in 1994)—Bedford Hills Facility, Sing Sing State Prison;

(3) Hudson Link-Nyack, Mercy College, etc. in 6 New York State Prisons; (4) Medaille College-Albion Prison;

(5) New Orleans Baptist Theological Seminary-Angola Prison; (6) Consortium of the Niagara Frontier; (7) North Park Theological Seminary-Stateville; (8) Schools for Alternative Learning and Transformation (SALT) (Vanderbilt Divinity School)—Riverbend Maximum Security Institution; (9) B.A. in Liberal Studies, Villanova University—Graterford State Correctional Institution.

10 We excluded the many religious institutions that offer education to incarcerated students via correspondence.

11 Due to America's religious history, there are relatively few institutions of higher education associated with religious traditions besides Christianity. Of those that we are aware, none have programs in prisons. While students from Yeshiva University in New York, NY sometimes travel to Northern State Prison in Newark, NJ as part of a social work class, their involvement is not yet a regular, sustained program that fit the parameters of our study (http://blogs.yu.edu/news/ the-impact-of-incarceration/). Brandeis University, also a Jewish university, contributes faculty to the Prison Education Program, housed at Boston University. The Chillon Project, offered by Life University, which was founded in response to an exhortation from the Dalai Lama, seeks to make a contemplative intervention in Georgia's prisons, and has designed their associate's degree program accordingly (http://www.compassion.life.edu/chillon-project/).

12 On religious instruction at the two prototypical prisons, Philadelphia's Eastern State Penitentiary and New York's Auburn Prison, see (Janofsky 2012; Graber 2014). 
incarcerated crossed over into institutions for religious higher education when, in 1834, thirty tutors from Harvard Divinity College convened weekly sessions with people incarcerated in Massachusetts State Prison (Gehring 1997).

Prison education was largely secularized during the progressive era. Pulled in part by the labor force requirements of urban industrialization, incarcerated people came to be regarded as capable of being reformed. As administered both by instructors on-site and via correspondence, vocational training became part of what American prisons did-at least in the North. In the South, where labor remained agricultural, education for prisoners was almost nonexistent (Williford 1994, p. 24). Even in the North, educational offerings were largely remedial. Here and there, experiments in higher education for prisoners were undertaken. In 1914, a group of Berkeley professors administered correspondence courses for men incarcerated at San Quentin, and in 1923, a group of Columbia professors took college-level courses to men at Sing Sing (Gehring 1997, p. 47; Williford 1994, p. 22). In the decades to follow, across the North and Midwest, faculty from a handful of land-grant colleges followed suit, offering as extension courses a variety of academic and vocational classes to incarcerated women and men (Williford 1994, pp. 23-24). The post-War period brought new experiments in greater number. In 1953, Southern Illinois University launched the first degree granting college-in-prison program when it enrolled 25 students at Menard State Prison. With state aid and university grants, Southern Illinois soon expanded its program to two other facilities (Taylor 1992, pp. 132-41). Over the decade to follow, with little outside funding, perhaps a dozen universities launched similar programs (Williford 1994, p. 8). ${ }^{13}$

The public funding for religious and educational programming in prison was further assured in 1965, when Lyndon Johnson, as part of his Great Society agenda, signed into law the Higher Education Act. The Act's Basic Education Opportunity Grants-better known after Claiborne Pell, the bill's Senate sponsor, as Pell Grants-brought college-in-prison into the mainstream. Two years later, the newly founded Office of Economic Opportunity launched "Operation Newgate", an ambitious college-in-prison program in five state correctional facilities in five inland states. Among its goals, the program sought to foster a campus-style experience inside prison walls and to support those who were released to finish their degrees. The coming boom was a decentralized movement (Williford 1994, p. 26). Among the early adopters were religious institutions such as Kentucky Wesleyan (Methodist) and Ashland University (Brethren) (Williford 1994, p. 27). After an exponential eruption at the outset, college-in-prison enjoyed steady growth. By 1973, data-collectors were able to identity 182 programs nationwide; by 1976, there were 237; and by 1982, there were 350. By the 1982 count, college-in-prison programs-both public and private, religious and secular, through universities and community colleges-could be identified in forty-five states and involved perhaps ten percent of the incarcerated population (Littlefield and Wolford 1982, pp. 14-18).

By the early nineties the prison population was skyrocketing, and a moral panic over violent crime drove policies that bent the curve ever steeper. In 1991, North Carolina Senator Jesse Helms introduced legislation to bar incarcerated people from receiving Pell Grants. As Helms laid it out on the Senate floor: law-abiding, taxpaying citizens, many of whom were struggling to find the money to send their own children to college, were footing the bill for criminals to go to college (Littlefield and Wolford 1982, p. 169). The legislation failed, but as a compromise, prisoners sentenced to death or to life without the possibility of parole were rendered Pell-ineligible.

In 1994, President Clinton signed into law the Violent Crime Control and Law Enforcement Act. Among its provisions was an amendment to the Higher Education Act of 1965 which read, "No basic grant shall be awarded under this subpart to any individual who is incarcerated in any Federal or State

13 Of those we have identified, the only one that was arguably "religious" was a program run at Leavenworth by the University of Kansas and St. Mary's College. 
penal institution."14 The consequences were devastating. Almost overnight, the textured institutional landscape of college-in-prison in America imploded. ${ }^{15}$ With internal support, New York Theological Seminary (nondenominational), Villanova University (Catholic), and Mercy College (formerly Catholic) muddled through on a shoestring, motivated by a perceived calling to overcome such obstacles and continue the work of teaching the incarcerated.

With the absence of Pell still palpable, private citizens felt called to fill the need. People of faith proved especially susceptible. Encouraged by his pastor, Burl Cain, the Warden of Louisiana's Angola Prison, called up New Orleans Baptist Theological Seminary to gauge its interest in providing educational services. With an eye toward training the leaders of Angola's sixteen different religious congregations, NOBTS launched its self-funded program in 1995. At the other end of the spectrum geographically and culturally, in 1998, a group of people incarcerated at Bedford Hills and Sing Sing, community leaders, and college educators formed the Hudson Link for Higher Education in Prison. Nyack College (Christian and Missionary Alliance) sponsored the degree-a BA in Organizational Management-and Mercy was a charter member.

This impulse proved infectious. Slowly at first and then with gathering momentum, university undergraduates, graduate students, and faculty, working within their own institutions and building bridges over prison walls, spearheaded dozens of new initiatives. Driven by commitments religious and secular, these were labors of love, recharged at every turn by what invariably proved to be thrilling and edifying pedagogical encounters. By the end of the decade, the good press heaped on some of the emerging cohort of secular programs garnered the attention of progressive foundations. In recent years, the support of Mellon, Soros, Ford, and the Sunshine Lady has allowed struggling programs to flourish and enabled other new programs to take seed.

We are presently in a new era, the contours of which are under contestation. In his final year in office, President Obama reinstituted Pell grants for incarcerated people on a pilot basis. Awarded to 67 prison education programs, some already in existence and some new, "Second Chance Pell" permitted 12,000 incarcerated people at 100 correctional institutions to be full-time students (Schwartzapfel 2015). Of the recipients, five are religious institutions-Ashland University (Brethren), Shorter College (AME), Wiley College (Methodist), Holy Cross College, and Villanova University (Catholic)—and two more, Mercy College and Manhattan Marymount, are formerly Catholic. ${ }^{16}$ Given that they represent over fifteen percent of universities and colleges nationwide, religious institutions were profoundly underrepresented in this pool.

Will federal support continue under Trump? Will debt-free college initiatives like that passed in New York come to include incarcerated people? Time will tell. If the United States is going to incarcerate so many people, it strikes us as appropriate and just for the state to pay for educating them, which nowadays must include college. The exclusion of incarcerated people from the Pell program is a typical detail in a grotesque portrait. Lest we succumb to nostalgia, however, it is important to observe that far from any kind of panacea, the Pell era college-in-prison boom was foremost a symptomatic feature of mass incarceration in an earlier stage. During the seventies and eighties, one might well argue, the patina of rehabilitationism afforded by higher education partners provided partial cover for the brutal expansion of the prison state. Nor should one fail to notice how, as the Prison Industrial Complex's ivory turret, Pell furnished a means for colleges and universities to convert incarcerated bodies into tuition dollars. This is not an argument against public funding for college-in-prison, simply

14 H.R.3355-Violent Crime Control and Law Enforcement Act of 1994, passed by the 103rd Congress (1993-1994) and was signed into law on 13 September 1994, https:/ / www.congress.gov/bill/103rd-congress/house-bill/3355/text

15 "In 1990, there were 350 higher education programs for inmates. By 1997 only 8 programs remained" (Mentor 2005, p. 142). See also (Coeyman 1998, p. B1). However, state-funded programs, particularly offered through community colleges, persisted in some regions (Messemer 2003, pp. 32-39; Wright 2001, pp. 11-16).

16 See the US Department of Education's 7 July 2016 list, https: / / www2.ed.gov/documents / press-releases/second-chancepell-institutions.pdf 
a note of caution that even with the state funding it deserves, college-in-prison is not inherently a decarcerating measure.

\section{Animating Intentions: Personal Commitments and Religious Motivations to Educate the Incarcerated}

What precisely gets people into this sort of work? To what degree do prison educators articulate their motivations in religious terms? The answers we received to these questions ranged widely, from proclamations of total secularity to fervent religious commitment to subtle reflections on institutional mission and personal calling. However, common to all respondents is a two-fold commitment that drives secular as well as religious prison educators: to the transformative potential of liberal education and a refusal to allow the conditions of incarceration to preclude access to this sort of education.

Consider, for example, Bill Webber, who launched New York Theological Seminary's program in 1982, and Bob Hausrath of the Consortium of the Niagara Frontier-a collaboration between three Catholic schools, Daemen College, Canisius College, and Niagara University—which he founded in 1975 and administered for forty years. Each describes a bedrock commitment to human dignity and the fulfilling potential of education, even and especially behind bars. For Webber, NYTS's program was founded to be a place where incarcerated people could "seek the Shalom" exactly where they were. He interprets the prophet Jeremiah's words in an address to incoming students: "You gotta be seeking the welfare wherever you are because that's what makes your humanity real, makes you a real person! It's what life is all about and you've got a chance to discover it anew!" Hausrath asserts, "Freedom isn't only outside the prison. Even in prison you're free to make decisions that begin to change your whole being. Education is about educating the whole person."

A sizable minority of the programs we surveyed provide what they might explicitly dub a "theological education". Universally in such programs, a particular faith commitment is not a prerequisite for student participation. In some cases—such as SALT, PREP, and Project TURN—-there is a good deal of variety among students' religious orientations, where in others-such as Princeton Theological Seminary and North Park Theological Seminary-outside educators work in close partnership with prison chaplains and cater primarily to a Protestant student body. Theological diversity is commonly configured not as an obstacle but as an asset. Such diversity is sometimes celebrated as modeling wider social change. The 1998 graduating class from New York Theological Seminary's program held themselves up as exemplary: "Interfaith collaboration, between Christians and Muslims, has worked within our group in prison, and it can work in our communities."

Given the complex institutional dance of administering prison education, programs' public faces do not necessarily provide an unfiltered window into prison educators' religious and political commitments. In toggling back and forth between university administration, prison administration, and outside funders, program leaders must communicate with audiences whose different interests and commitments necessitate frequent and artful code switching. As we saw with the origin story of SLU's program, for prison administrators and prison educators alike, the go-to public languages for justifying college-in-prison programs are secular and practical, and they primarily pertain to the goals of producing "prosocial behavior" presumed to facilitate eventual reentry and to reduce recidivism. On top of those reasons, however, SLU's program is firmly rooted in the institution's Jesuit identity and the spirituality of Ignatius of Loyola. Given the complex commitments of different constituencies involved in sustaining the program, different presentations of the program's motivations are required.

As Kenneth Parker's story features prominently, showing how to tactically leverage institutional missions to secure administrative buy-in is one of the things that religious prison education has to offer all would-be prison educators. Many university leaders are swayed by appeals to their institution's mission or the benefits that will accrue to on-campus students; meanwhile, faculty are often motivated by the opportunity to pursue social justice while practicing their craft with students who are excited to learn; and granting agencies are motivated by the far-reaching communal impact of bettering the 
lives of those in prison, which also has the potential to interrupt cycles of violence and trauma in incarcerated students' families and wider social circles.

How precisely to describe this aspiration to effect social change is fraught terrain. Word choice can trigger deep contention. For some doing this work, "public service" is worn as a badge of honor; for others, this rubric reeks of condescension. Many program leaders stress the importance of using language that underscores their incarcerated students' personhood. Phrases such as "people in prison", "incarcerated students", or "inside students" are favored and those who speak of "inmates", "convicts", or "prisoners" are regarded with distrust. However, when talking with prison staff, this humanizing or civil language can be a distraction, if not an outright impediment, to successful collaboration. To achieve smooth working relationships with prison officials, program leaders frequently default to the commonplace euphemism of "inmates".

The incarcerated students are not seen as the only ones being edified. Within the liberal theological stories of self that predominate, the incarcerated students are ceded no monopoly on brokenness. For many, the transformation being sought is as much of the nonincarcerated participants as the incarcerated ones. In addition, program leaders at Grinnell College, Princeton Theological Seminary, and Greenville College emphasize the importance of helping incarcerated students develop capacities that position them to transition back to the free world and to strengthen the communities to which they return. Some program leaders note, though, that narrow focus on reducing recidivism shifts attention away from those whose release is a long time away, suggesting that education is somehow less important for those with decades left on their sentences or who have been sentenced to die in prison. ${ }^{17}$ For most, the project of repair is by no means limited to individual program participants. The "Get Booked" program offered by North Park Theological Seminary in Stateville Correctional Center near Chicago, which was launched in 2015, is developing a theological framework premised on the logic of reparations. Michelle Clifton-Soderstrom, who is an ethics professor at the evangelical NPTS, appeals to reparations in order to turn the discussion around prison work away from the rhetoric of personal salvation. That is, teaching in prisons is not about saving students' souls but is rooted in recognition of the history of societal injustices that have caused black and brown communities to be disproportionately impacted by America's prison-industrial complex. Drawing on Harvey's Dear White Christians (2014), Clifton-Soderstrom argues that "white Christians need to stop using reconciliation language and start thinking about reparations more." When talking with school administrators, Clifton-Soderstrom draws on North Park's informal missional claim that "Chicago is our classroom" to argue that this includes not only art institutes, theaters, and the Riverwalk, but also the area prisons that warehouse the city's missing.

Other programs see the prison as a lab for experiments in how to transform theological education into an effective instrument for broader social transformation. Founded in 2002, Schools for Alternative Learning and Transformation (SALT) at Tennessee's Riverbend Maximum Security Institution seeks to reimagine theological education as centered within communities, particularly prisons, rather than in theological institutions. Doing theology biblical exegesis, history, and pastoral care in partnerships across prison walls recenters the task and contributions of theological engagement. SALT was first organized as a "think tank" at the prison, bringing together incarcerated participants and Vanderbilt University students. Program founder Janet Wolf draws on both Matthew 25 and Ubuntu theology to frame the significance of the model that SALT has designed. To respond to the question from Matthew 25:44: "Lord, when was it that we saw you ... ?" she turns to Ubuntu theology's dual foci of seeing and being seen, of recognizing another's humanity and letting others see oneself (Wolf 2012, pp. 252-71). This practice depends on mutuality. Its central motivation is to create a space of radical and critical equality in which all participants are both teachers and students as they see and are seen

17 Whereas in other programs a long outstanding sentence can disqualify a person from program participation, in NOBTS's program, a long sentence is a prerequisite. All participants must have at least 20 years remaining in their sentence. 
by one another. To enact this theological frame and to foster the resulting community, SALT's classes contain a combined cohort of incarcerated and nonincarcerated participants. ${ }^{18}$

Inspired by SALT, the founders of Project TURN created courses for Duke Divinity School students alongside incarcerated students at five North Carolina prisons. For outside students these courses fulfill M.Div. requirements toward a Certificate in Prison Studies while inside students work toward a Certificate of Achievement in Theological Studies. Project TURN's founders, Sarah Jobe and Jonathan Wilson-Hartgrove, attest that "bringing people together, who are not often brought together, to learn alongside one another can effect transformation of individuals and the social structures and social mindsets that uphold racism, sexism, classism, and mass incarceration." Insights gleaned from incarcerated women and men in prison classrooms filter back to chaplaincies, churches, nonprofits, and into Ph.D. programs. Formerly incarcerated SALT alumni have created an informal network through which they plan to attend, in groups, an academic institution so that the communal system developed through courses on the inside might translate to greater chances of success and endurance on the outside. Project TURN is also invested in fostering a "prison to secondary education pipeline." In this way, not only do these programs bring traditional students into the nontraditional learning environment of the prison classroom, they position nontraditional (formerly incarcerated) students to pursue higher education in traditional settings.

The theologically conservative New Orleans Baptist Theological Seminary is hardly the only program that considers its students' impact on the culture of the prison. In the Certificate in Theological Studies (CTS) program offered by the Atlanta Theological Association, M.Div. students and Ph.D. students from four member seminaries offer certificate courses at Arrendale State Prison and Metro State Prison in their area of specialty. These graduate students enter the prison not as outside students, as with the SALT and TURN models, but as instructors. Yet, the CTS program offers the language of "teacher-students" and "student-teachers" in order to emphasize that all bring wisdom to share and a need for the wisdom of others in the learning community. CTS aims to "nurture [the students'] intellectual passions along with their drive to engage and transform the world around them." For example, as a capstone project for their advanced certificate, two students recognized a need for a theological library to supplement their course texts and they developed one, which is housed within the main prison library. It now carries hundreds of theological and religious studies books and continues to grow. The two students serve as the librarians, managing the holdings and creating policies for its use. Their contributions exemplify the claim that 2015 CTS graduate Tracy Kohnle made in her graduation speech: "Behind these walls, only the strongest can endure the harsh realities and still remain compassionate ... . Theology nurtures the best part of us, individually, and helps mold us into something much greater, as a community."

These theological wrinkles notwithstanding, the motivations articulated by religious prison educators are widely similar to those articulated by secular prison educators. Administrators for Indiana Women's Prison Higher Education Program, who expressly disavow any religious motivation for their program, also describe prison education as a means for effecting social change: "We believe that a liberal arts education can be transformative for men and women in prison in ways that are beneficial not only to them, but also to their families and to the communities of which they are a part-including their prison and college communities." With this goal in mind, class projects regularly become platforms for public education. Indiana students have written and presented studies on the history of prisons, gynecology, and eugenics via video conferencing to the American Historical Association. Others prepared and delivered via video conferencing a proposal regarding a public

18 This tactic is by no means limited to religious programs. The Inside-Out Prison Exchange Program certifies instructors to teach classes of incarcerated "insiders" and college-student "outsiders." Though not a religious program (and consequently not a focal point of this research), Inside-Out leans heavily on the language of "transformation." See http://www.insideoutcenter.org/. For a critical appraisal, see (Dunn 2009). 
policy issue before a joint legislative committee at the Indiana General Assembly, which unanimously endorsed the proposal.

\section{Challenges for Religiously Affiliated Prison Education Programs}

The challenges faced by religiously affiliated prison education programs are for the most part not distinct from those that confront all college-in-prison programs, and, in times of crisis, being religiously affiliated can be strategically advantageous.

With the state having retreated from the obligation of paying for incarcerated people's higher education, the primary obstacle every program faces is financial. To administer a program of this sort requires perpetual hustle: university administrators must be lobbied to offer credits pro bono and course releases, grant applications must be written, and foundation funders must be wooed. It is a constant struggle, but unique solutions may be arranged. From the end of Pell until 2002, the Consortium of the Niagara Frontier ran off monies saved by the Consortium during the Pell era, and it subsisted thereafter on a state budget line item earmarked on its behalf. The nonprofit Hudson Link for Higher Education in Prison was established to fill the gap created by the end of Pell funding and is supported in large part by private foundations, a few of which, such as Episcopal Charities, are faith-based. ${ }^{19}$ A few programs get by exclusively on volunteer labor, and others on adjunct staff. To one degree or another all rely on support from higher education institutions, which in most cases includes financial support. Sometimes this means a disbursable budget, sometimes it means in-kind contributions such as donated credits or faculty course releases, and sometimes it means administrative support. In other cases, money is primarily raised through cooperation with development offices and institutional alumni networks. In one innovative arrangement, Donnelly College's program was launched as a partnership with a private business that employed those incarcerated at a particular prison, and the employer agreed to assume one third of the cost of classes, with Donnelly and the incarcerated student each assuming the remainder. ${ }^{20}$ Only in two of our surveyed programs are incarcerated students expected to pay a share of the cost of their education.

Prison administrators, and the security-minded practices and norms of correctional institutions more generally, offer up a range of other challenges. Prisons are hierarchical, with power concentrated at the top and often wielded with a swiftness and arbitrariness well outside the comparatively genteel norms of university life. ${ }^{21}$ Course texts are subject to review and to censorship. Without warning, incarcerated students may be dropped from the program for disciplinary infractions, placed in custody, or transferred to another prison. Changes in staff, and particularly in administrative leadership, can have significant effects on the ability of programs to operate. To navigate this challenge, some respondents stress the need to build multiple relationships across institutions, both at the prison and at the university. In several cases these processes are smoothed over by prison staff who happen to be alumni of the educational institution..$^{22}$

Incarcerated students come with a wide range of academic abilities, and developing fair but functional criteria for student selection presents another common challenge. Some programs administer admissions tests; others do not. Some programs offer not-for-credit remedial courses for new students.

19 See also: "History of Hudson Link for Higher Education in Prison," http://www.hudsonlink.org/what-we-do/history/, accessed 18 October 2018.

20 The business subsequently pulled out of this arrangement; now incarcerated students pay $\$ 71$ per credit and Donnelly contributes $\$ 204$ per credit itself.

21 It is precisely because of the arbitrariness of the power wielded within prison contexts that we do not link obstacles with programs in the present discussion.

22 In some facilities, education programs are located within the chaplaincy office area, in others, within the recreation department, and in others, within an education department—and are affected in each case by the bureaucratic quirks and personal whims of these units. Related challenges include coordinating prison calendars with academic calendars and resource competition with other programming inside correctional facilities. 
Many programs administer orientations, often designed with students, to introduce new students to higher education and to introduce new instructors to teaching in a prison environment.

Racial dynamics haunt prison education in any number of ways beyond the obvious fact of the overrepresentation of black and brown people in our prisons. Admission procedures can reinscribe class stratification that might align with race. Recruiting faculty of color can be a challenge, and the resulting dynamic of an overwhelmingly white professoriate teaching a student body that consists overwhelmingly of persons of color is certainly grounds for concern. The issue of race can be meddlesome-with prison administrators for whom it might trigger "security" concerns or with students who might feel objectified—but it can also be an object of self-reflective study in the classroom.

The coordination and instruction of university courses in a prison classroom presents a variety of logistical hurdles. How can science classes be conducted without laboratory equipment? How can historical research be conducted without access to a research library or archives? How can anything happen without the internet? Programs we surveyed developed a range of creative responses to questions such as these. For example, an ecology class without access to a formal laboratory can still conduct observations on the birds, mice, and other animals that inhabit a prison. As subject to local restrictions, instructors are able to supplement course texts with primary sources or archival material for research. In some cases, computers without internet connections are available for student use.

A final set of challenges involve course accreditation. Some of the programs we surveyed directly offered their own courses inside prison and so avoided accreditation worries. Other institutions, particularly those with a focus on ministry, offered certificate programs that are recognized by the sponsoring institution but are not accredited by an external body, such as the Association of Theological Schools. Still other institutions creatively forged partnerships in order to assure that the credits incarcerated students completed could be transferred and count toward a degree postincarceration. In addition to credits and degrees, a significant benefit of college education to incarcerated students is the social capital gained by association with that college's network of students, alumni, and faculty. The integration of formerly incarcerated students on campus proved a particularly fraught subject among the programs we studied, and responses varied widely. Some universities were concerned about having formerly incarcerated students on their own campus or associated with their alumni community while other universities embraced formerly incarcerated students and welcomed them. Most often we found something in between: informal alumni networks cultivated by students themselves and sometimes program leaders but held at a distance by university administrators.

Prison educators working at schools with explicitly religious missions may enjoy one significant advantage over their institutionally secular colleagues. When crises arise-and in prison education crises inevitably arise-religious languages furnish a powerful set of tools with which to appeal, if not necessarily to correctional staff, then at least to one's own university community. In the summer of 2000, Villanova came under fire from conservative talk radio after an article about its Graterford program ran in a university publication. In a letter to an aggrieved alumnus who asked rhetorically what Villanova "owed" to convicted murderers, longtime instructor Joseph Betz replied:

We at Villanova do not think that we "owe" prison inmates this education. We would use the language of Christian love and charity in which there is no debt to be repaid. Kindness to the marginalized is done for the sake of clarifying the image of God in the recipient, not because of the recipient's desert... As the church encourages repentance and facilitates internal conversation, so does Villanova at Graterford. We try to act at Graterford as Christ would.

Betz's appeal to "Christian love and charity" carried the day. In the face of the public firestorm, University administration stood fast. Eventually the crisis died down. With the institutional force furnished by the Villanova's Augustinian mission, the University reaffirmed its commitment. The program kept on as before. 


\section{Pedagogical Paradigms}

Among our surveyed programs, we identified two dominant pedagogical paradigms-radical teaching and concept critique. Neither of the pedagogies are explicitly religious or overwhelmingly secular, but both fit into a dominant philosophy of education: transformative education. ${ }^{23}$

The first pedagogical paradigm, the "radical teaching" approach, is exemplified in the widely franchised Inside-Out Prison Exchange Program and takes its point of departure from theorist Paolo Freire. According to this pedagogical approach, empowering incarcerated persons and repairing society more broadly begins with structuring the classroom in a radically egalitarian way. Pursuant to this model, teachers are encouraged to invert the classroom and to empower incarcerated students to take the lead. In practice, this engenders a populist attitude that privileges a diversity of forms of knowledge and experience. By empowering incarcerated students to speak their own individual truths, true to their personal experience, incarcerated men and women can both grow their confidence and their esteem. By empowering these frequently silenced people with a voice, incarcerated students may in turn supplement and correct important oversights in the public discourses from which they have largely been excluded (Scott 2013, pp. 22-32).

The second paradigm is what Bard Prison Initiative founder Daniel Karpowitz calls the "concept critique" approach. According to this approach, incarcerated students are best served by a more traditional, hierarchical classroom. Incarcerated students are thought to benefit from sober instruction that emphasizes objectivity over subjectivity, and "structure" over the concept of the "autonomous individual". By teaching in this manner, instructors not only endow the critical reasoning skills that students need to flourish, they also disseminate an analytic approach that whittles away at the dominant framing where the problem of crime is thought to be solved solely by incapacitating "bad guys" (Karpowitz 2005, p. 312; Karpowitz 2017).

In their response to our survey, the Lansing program cited Karpowitz explicitly. They explained their pedagogy as "a practice, under conditions of incarceration, in which (i) the moral agency of the student is actively engaged in non-punitive ways, (ii) their dignity as human agents is respected and amplified." The program encourages "students to become close readers of texts, critical thinkers about social concepts, and articulate analysts of the social structures within which individuality and moral agency are themselves constructed." In some programs, religious mission is presented as resonating with Karpowitz's view of the dynamics at play within the prison classroom. Manhattan College's E3MC program, firmly situated within the LaSallian Brotherhood, a movement within Catholicism that privileges the poor, articulates its pedagogy as follows:

The class is interactive, attempting to maximize the opportunity for the students from our main campus to speak with, mentor, and be mentored by the incarcerated students ... For the incarcerated students the class provides [opportunities for them to be] challenged by taking a demanding college course, but they are also reminded or, perhaps, introduced to the fact that they are just as natively bright and educable as any other men or women in our society. The students treat each other as equals in all linguistic, educational, and pedagogical aspects.

E3MC seeks to actively engage the moral agency of on-campus and incarcerated students alike, placing them in relationships of mutual mentorship and so respecting and amplifying their human dignity. The interactions conducted and skills gained within the classroom serve to affirm students' place within a wider learning community and so invite students to envision possibilities for social

23 According to two of the most influential proponents of transformative education, Loder (1989), a Christian educator, and Mezirow (1991), a secular educator, personal transformation begins with a conflict or disorienting dilemma that causes a person to question his or her assumptions and to seek new perspectives. The transformation of meaning is complete once the person goes through an interpretation of the new perspective by explaining what she has realized and seeking agreement on the new perspective from the person's community. 
transformation that attend to but are not limited by the social structures manifested by the prison's walls.

While E3MC is a liberal arts program conducted through a religiously affiliated institution, the Certificate in Theological Studies offered by the Atlanta Theological Association is both religious in affiliation and in subject matter. The program's goals also resonate with those articulated by Karpowitz:

The academic goals include the development of critical thinking skills ... Critical thinking and writing skills are necessary for the articulation of a deliberative theology and also help prevent inmates from accepting society's or individuals' negative characterizations of them. Academic development also includes familiarity with basic scriptural and theological information and concepts as well as an understanding of the breadth and depth of Christian traditions and the variety of streams of thought.

The CTS program seeks critical thinking and writing skills as tools for combatting the stigmas associated with labels such as "criminal" and "prisoner". The aims that Karpowitz identifies, and that Lansing affirms, are achieved through engagement with scriptural and theological resources within different Christian traditions.

Not only does CTS's language resonate with Karpowitz's aims, but the program also attempts to provide "a dialogical model of education versus a banking model," and it explicitly claims inspiration from the Freirian and "radical teaching" approach. Elizabeth Bounds, the program's founder, mitigates any claim to "liberatory education"; however, noting the "bureaucratic constraints that naturally work against this in the prison setting." The Freirian model of pedagogy, which seeks radical equality in the classroom, has shaped not only secular programs like the Inside-Out Prison Exchange Program, but motivated, for instance, the formation of "think tanks" at Riverbend Prison as part of the founding of SALT, the emphasis on mutuality in Princeton Theological Seminary's program, and CTS's identification of all program participants as both teachers and students.

The programs we surveyed employed the language of student transformation in a variety of contexts, and according to our research they deployed techniques that could be grouped into seven categories in order to facilitate such transformation. Common techniques include (1) critical thinking about personal perspectives and beliefs through course content, (2) critical thinking about personal perspectives and beliefs through discussion, (3) critical thinking about personal perspectives and beliefs through writing exercises ${ }^{24}$, (4) class projects that seek to improve incarcerated or free world communities, (5) the regular inclusion of religious practice during classes, (6) intentional creation of a space for inside and outside students to learn and share their diverse perspectives, and (7) before the outside instructors and students participate in a prison education program, they receive intentional training that orients them toward methods of transformational education and their creative applications in prison.

Some of the more theologically-oriented programs (such as Greenville College, Manhattan College, and SALT) explicitly posited that the content of their courses invoked the transformative power of the Holy Spirit. In some liberal arts programs (including Villanova and Saint Louis University) the theological mission is credited as providing scaffolding, and individual instructors invoked the Holy Spirit as a force of transformation, but such ideas are wholly distinct from the curriculum. In yet other programs, such as Manhattan College, Lansing College, Duke's Project TURN, and Riverbend Prison's SALT, secular content and a liberal arts pedagogy are presumed to invoke spiritual transformations. Explicit claims about transformation were especially prominent among the two-thirds

24 All of these methods to encourage critical thinking could follow several philosophies including but not limited to a partial Freirean or problem-posing (or question-focused instead of answer-focused) method that intellectually and theologically challenges individuals. 
of surveyed programs that include, alongside incarcerated students, students from campus or the wider community. ${ }^{25}$

The majority of the programs surveyed used six of the seven common interpretations of the radical teaching and concept critique paradigms that could lead to the critical reflection necessary for transformational education. However, most did not include any religious practice that expressly invoked the divine in the classroom community. Every program surveyed encouraged critical thinking about personal perspectives and beliefs through course content, discussion, and writing exercises-hallmarks of a transformative education philosophy. ${ }^{26}$ In some cases, this emphasis was theologically inflected; in others, the theory and practices of transformation were articulated solely through the language of the secular liberal arts. Consequently, if, following Erzen's lead, we are to paint the rubric of "personal transformation" as being problematic, it strikes us as fairly arbitrary to single out "religious" programs for special criticism while absolving those framed in secular terms from the same judgment.

\section{Conclusions}

Some critics take precisely this condemnatory tack. If for Erzen "personal transformation" is a marker that a given prison education program has succumbed to neoliberal hegemony, other scholars have broader worries. For abolitionist scholar Dylan Rodriguez, for example, college-in-prison is essentially a sentimental, orientalist exercise that exploits the voiceless for reactionary ends (Rodríguez 2004, pp. 75-112). From this perspective, to collaborate with carceral authorities is to burnish the legitimacy of the carceral regime.

One need not go quite that far and still concede the fundamental conservatism of the college-in-prison project. These programs focus on the empowerment of particular-in many ways, exceptional-individuals, and they seek to endow the analytic abilities and social capital necessary for such individuals to pull themselves up above their allotted station. For a project that regularly boasts of its intention to broad social transformation, college-in-prison would seem to run on decidedly regressive assumptions and attitudes. From a practical perspective, what of the many incarcerated people who are illiterate, mentally ill, or are otherwise excluded from participating in such programs? Is it possible that as educators we are ethically and institutionally bound to only the most privileged and talented of the incarcerated?

The seemingly charitable nature of the enterprise also seems suspect. While historically conversations about religious response to prisons were often framed in terms of charity, today they are increasingly framed in terms of justice: inhuman prison conditions, racially disproportionate prison populations and prison sentences, continuing social marginalization after release, not to mention policing that targets racially and economically disadvantaged communities leading to imprisonment in the first place. Where does this leave the prison educator? In some ways, they seem a relic of the charity era, at odds with a call to justice that manifests as a call to end mass incarceration, or more strongly, to abolish prisons. In the new justice frame, charity projects seem troublingly entwined with the practices, institutions, or logics of mass incarceration. Simply put, for prison education to thrive, there must be men and women incarcerated-the more who are incarcerated, the more there are to fill seats in the classroom. Prison education would seem to focus on an immediate need of incarcerated

25 The inside-outside dynamic calls for what can be a burdensome negotiation with academic and correctional institutions to allow for the adequate preparation of physical space at the prison and for the psychological preparation of the students and staff in order to create an effective learning community. Having classrooms with only incarcerated students also reduces the risk to those students; fewer outsiders means fewer well-meaning mistakes that might compromise the good standing of an inside student. In one program, an outside student naively brought (prohibited) cash to inside students, resulting in months of solitary confinement for one inside student.

26 The Walls to Bridges program was the only one that did not seem to emphasize writing assignments for its program participants-perhaps due to limits of time and space. 
individuals while ignoring, or even running against, the longer term and much more significant need of incarcerated individuals: to be freed.

Just as we are not ready to dismiss "personal transformation", we are wary of dismissing charity. In the present political climate, crowdsourcing initiatives and, perhaps more pointedly, community bail funds are vital organizing measures. From the instructor's standpoint, framing prison teaching as an act of charity does not strike us as ideal. Prison teaching is labor, and it ought to be compensated as such. But from an institutional perspective, harnessing university resources for the purpose of educating people incarcerated in our communities does exhibit the logic of charity, but it also exhibits the logic of resource expropriation, and potentially also, the logic of reparations. Taken seriously, "Christian love and charity" demand significantly more than a handout to inoculate the givers against injustice; they demand that the givers throw themselves, body and soul, into the struggle.

We do not want to overstate the case. It is a dangerous vanity to mistake educating incarcerated people for a revolutionary praxis. Given the moral and social abomination for which, as Americans, we are collectively responsible, teaching a religion class to a group of incarcerated people is not nearly enough. As an ethnographic matter, however, it is the case that the overwhelming majority of prison educators see their work as closely tied to the project of radical prison reform or prison abolition. For some, teaching incarcerated men and women is their way of contributing to this project. If those most affected by an injustice ought to lead the struggle against that injustice, it is crucial to equip those who are incarcerated with the tools that an education can provide. Meanwhile, at the micro level, what happens in a prison classroom does not stay there. Consistent with NOBTS's theory, those who pursue degrees and certificate programs become leaders on their cell blocks, in their religious communities, and in their prisons' civil society. In prison and eventually out, they may become a force for good in their communities. One may be skeptical of prison educators' more ambitious visions of social transformation, but these yields are material and measurable.

The same ripples may be felt on campus. Going into a prison feels weird and exciting, and primes the prison educator for the unexpected. Put simply, the dehumanizing and simplistic ideas we have in this culture about incarcerated people are, as a general rule, difficult to sustain in practice. ${ }^{27}$ Meanwhile, starved of enriching social practices, for many incarcerated college courses are a lifeline, and often to a stunning degree, as students, they bring it. With these factors all in play, almost invariably, a prison classroom is a charged educational environment in which extraordinary things happen. The magic of the pedagogical encounter takes over. It is difficult to leave such an experience unchanged, and difficult to leave such an experience with the sense that a criminal justice system that relegates millions to cages is just or wise. The educator is primed for political engagement. Fueled by these pedagogical encounters, prison educators can begin to catalyze the decarceration of our own communities. This fight begins with the struggle to integrate our incarcerated and formerly incarcerated students into our institutional lives, in area prisons and on-campus.

We do not believe this calculus is easy or clear-cut. There is a difficult balance to strike between the moral harm of complicity with the prison system and the benefit of the moral awareness brought about by being a prison educator. There are many religious studies scholars already trying to strike this balance-and in this essay we have attempted to honor their work. For those looking to newly engage with prison education, we have offered stories and resources that can aid in clarification, and that can help those who decide to participate in education programs to thrive. Indeed, the moral tension that animates prison education in no way dissipates once one embraces the work. Indeed, the deeper one goes, the thornier things get. We have already noted educators' code switching: speaking to prison administrators using an administrative idiom, speaking to activists in a reformist or abolitionist idiom, and speaking to colleagues in whichever of these idioms seems the most persuasive. Such are the compromises on which an enduring college-in-prison program stands.

27 But note Scott's (2013) worry about the judgment distorting “high" prison education produces. 
As we saw in our introductory parable, prison programming generally justifies itself by appealing to the relationship between education and recidivism rates. Recidivism matters-to our incarcerated students more than anyone-but the scant attention paid to the issue of recidivism in this article is not incidental. Not solely is this because the widely circulated RAND study that claims that taking even just one college class substantially reduces recidivism rates is based on data sparer than one might wish. ${ }^{28}$ It is also because, as political scientist Marie Gottschalk argues, a mechanistic preoccupation with recidivism, which places responsibility on individuals who "fail" and absolves the structures that set them up to fail, cannot dislodge the carceral state. ${ }^{29}$ To end mass incarceration, a far more radical shift in political frame is required. As we have shown, scholars operating pursuant to explicitly religious missions have much to offer this fight.

So too, we might add, do secular scholars of religion. As is true of our religiously identified colleagues, secular scholars of religion are also unlikely to reduce the value of education to any unidimensional outcome. As our discipline is especially adept at articulating, the critical study of any subject has the power to change the student and their relationship to the world. These processes, and the many moments of insight along the way, are, we believe as educators, goods unto themselves, and are essential components of a good life. In an era when the humanities are perpetually under fire for their alleged uselessness, foregrounding the power of humanities education for incarcerated people can remind our administrators of the monumental stakes of the humanist enterprise.

Too often, the bold humanist defense of college-in-prison is absent from the public conversation. It is in this regard that the religious scholar and/or scholar of religion is primed to make unique contributions, both in the classroom and out. Just as in the classroom, a sensitivity to religion can be an invaluable resource in reaching and connecting with students with strong faith commitments, in the public square, in the fight against America's massive carceral state, religious scholars and scholars of religion may contribute normative arguments. As abolitionist organizer Mariame Kaba frequently exhorts, "We must make moral arguments." Just as helping a few individuals be extraordinary and rise above their station is grossly inadequate to the task at hand, sticking narrowly to recidivism statistics simply will not do. Both privately, to our administrators, and, vocally, in the public square, we must argue clearly, and on principle: Even were we talking hundreds and not millions, relegating people to cages is wrong. Human beings are entitled to more than captivity. Among those things to which human beings are entitled is an education.

Author Contributions: All authors contributed equally to research and writing.

Funding: This research was funded by an American Academy of Religion Regional Development Grant, a Louisville Institute Project Grant for Researchers, and a Wabash Center for Teaching and Learning in Theology and Religion Project Grant.

Conflicts of Interest: The authors have no conflict of interest.

\section{References}

Alexander, Michelle. 2012. The New Jim Crow: Mass Incarceration in the Age of Colorblindness. New York: The New Press.

Castro, Erin L, Michael Brawn, Daniel E. Graves, Orlando Mayorga, Johnny Page, and Andra Slater. 2015. Higher Education in an Era of Mass Incarceration: Possibility Under Constraint. Journal of Critical Scholarship on Higher Education and Student Affairs 1. Available online: https:/ / ecommons.luc.edu/jcshesa/vol1/iss1/2 (accessed on 22 October 2018).

Coeyman, Marjorie. 1998. Maximum-Security College. The Christian Science Monitor, June 30, B1.

28 (Davis et al. 2013) For an assessment of the data, see (Lagemann 2016, pp. 37-44).

29 Gottschalk refers to recidivism, reentry, and justice reinvestment as the "three R's." So long as the critical discourse remains limited to these concerns, she argues, we will do nothing to dislodge mass incarceration. See (Gottschalk 2016, p. 15). 
Davis, Lois M., Robert Bozick, Jennifer L. Steele, Jessica Saunders, and Jeremy N.V. Miles. 2013. Evaluating the Effectiveness of Correctional Education. Available online: http:/ / www.rand.org/content/dam/rand/pubs/ research_reports/RR200/RR266/RAND_RR266.sum.pdf (accessed on 6 February 2019).

Dunn, Kerry. 2009. Reforming the Social: Neoliberal Volunteeerism in the Warehouse Prison. Ph.D. Dissertation, University of Pennsylvania, Philadelphia, USA.

Earhart, Jim. 2014. Overcoming Isolation: A College Program Challenges Prison Culture through Engagement. Saint Louis Public Law Review 33: 329-41.

Erzen, Tanya. 2017. God in Captivity: The Rise of Faith-Based Prison Ministries in the Age of Mass Incarceration. Boston: Beacon Press.

Forman, James, Jr. 2012. Racial Critiques of Mass Incarceration: Beyond the New Jim Crow. NYU Law Review 87: 101-46.

Gehring, Thom. 1997. Post-Secondary Education for Inmates: An Historical Inquiry. Journal of Correctional Education 48: 46-55.

Gottschalk, Marie. 2016. Caught: The Prison State and the Lockdown of American Politics. Princeton: Princeton University Press.

Graber, Jennifer. 2014. The Furnace of Affliction: Prisons and Religion in Antebellum America. Chapel Hill: University of North Carolina Press.

Harvey, Jennifer. 2014. Dear White Christians: For Those Still Longing for Racial Reconciliation. Grand Rapids: Eerdmans.

Janofsky, Jennifer. 2012. Hopelessly Hardened: The Complexities of Penitentiary Discipline at Philadelphia's Eastern State Penitentiary. In Buried Lives: Incarceration in Early America. Edited by Michele Lise Tarter and Richard Bell. Athens: University of Georgia Press, pp. 106-23.

Karpowitz, Daniel. 2005. Prison, College, and the Paradox of Punishment. In Crime and Punishment: Perspectives from the Humanities. Edited by Austin Sarat. Amsterdam: Elsevier, pp. 305-31.

Karpowitz, Daniel. 2017. College in Prison: Reading in an Age of Mass Incarceration. New Brunswick: Rutgers University Press.

Lagemann, Ellen Condliffe. 2016. Liberating Minds: The Case for College in Prison. New York: The New Press.

Littlefield, John F., and Bruce I. Wolford. 1982. A Survey of Higher Education in U.S. Correctional Institutions. Journal of Correctional Education 33-4: 14-18.

Loder, James Edwin. 1989. The Transforming Moment. Colorado Springs: Helmers and Howard.

Mentor, Kenneth. 2005. College Courses in Prisons. In Encyclopedia of Prisons and Correctional Facilities. Edited by Mary Bosworth. Thousand Oaks: Sage Publications, p. 142.

Messemer, Jonathan E. 2003. College Programs for Inmates: The Post-Pell Grant Era. Journal of Correctional Education 54: 32-39.

Mezirow, Jack. 1991. Transformative Dimensions of Adult Learning. San Francisco: Jossey-Bass.

Parker, Kenneth L. 2014. The Saint Louis University Prison Program: An Ancient Mission, a New Beginning. Saint Louis University Public Law Review 33: 377-99.

Rodríguez, Dylan. 2004. Forced Passages: Imprisoned Radical Intellectuals and the U.S. Prison Regime. Minneapolis: University of Minnesota Press.

Schwartzapfel, Beth. 2015. Obama is Reinstating Pell Grants for Prisoners: But will Politics Eventually Trump Cost and Data? The Marshall Project: Nonprofit Journalism about Criminal Justice. Available online: https://www. themarshallproject.org/2015/07/30/obama-is-reinstating-pell-grants-for-prisoners\#.lwIKMeAUQ (accessed on 6 February 2019).

Scott, Robert. 2013. Distinguishing Radical Teaching from Merely Having Intense Experiences While Teaching in Prison. The Radical Teacher 95: 22-32. [CrossRef]

Stern, Kaia. 2014. Prison Education and Our Will to Punish. Saint Louis Public Law Review 33: 443-58.

Taylor, Jon M. 1992. Post-Secondary Correctional Education: An Evaluation of Effectiveness and Efficiency. Journal of Correctional Education 43: 132-41.

Wacquant, Loïc. 2010. Class, Race, and Hyperincarceration in Revanchist America. Daedalus 139-3: 74-90. [CrossRef]

Williford, Miriam, ed. 1994. Higher Education in Prison: A Contradiction in Terms? Phoenix, AZ: Oryx Press. 
Wolf, Janet. 2012. To See and Be Seen. In And the Criminals with Him: Essays in Honor of Will D. Campbell and All the Reconciled. Edited by Richard C. Goode and Will D. Campbell. Eugene: Wipf \& Stock, pp. 252-72.

Wright, Mary C. 2001. Pell Grants, Politics, and the Penitentiary: Connections Between the Development of U.S. Higher Education and Prisoner Post-Secondary Programs. Journal of Correctional Education 52: 11-16. 